\title{
Covid-19: impact on agricultural and anticipate strategies
}

\author{
Wa sito $^{1}$, Hari Hermawan ${ }^{1}$, Joko Mulyono ${ }^{1}$, Enti Sirna wati ${ }^{1}$, Yennita Sihombing $^{1 *}$, and \\ Dian Nur Ratri² \\ ${ }^{1}$ Balai Besar Pengkajian dan Pengembangan Teknologi Pertanian, Jl. Tentara Pelajar No. 10, Bogor, \\ 16114 \\ ${ }^{2}$ Badan Meteorologi Klimatologi dan Geofisika
}

\begin{abstract}
The increasingly widespread of the Covid-19 virus in various countries worldwide has suppressed global economic growth, including Indonesia. The pandemic also impacts on agricultural sector especially on food production, distribution, consumption, and potential for a food crisis. The agricultural sector is the last sector that can withstand any shock. This paper aims to bring information impacts the Covid-19 outbreak has on the agricultural sector, and propose strategies and action for the Indonesia Government in maintaining the stability of the agricultural sector during and after Covid-19. This study uses a qualitative descriptive analysis by describing the phenomena that occurred in the agricultural sector as an impact of Covid-19. The increasing spread of the Covid-19 outbreak has led to a decline in the performance of the agricultural sector. Covid-19 pandemic has an impact on reducing production by $5 \%$ due to distraction on the distribution but at the same time, food needs have increased by $5 \%$ due to panic buying and decreased import by $5 \%$ due to limiting exports. In addition, it also affects the food supply chain, and the threat of food insecurity due to the spread of Covid-19 to villages that are food producers and an increase in unemployment. Therefore Reorienting policy and programs in agriculture and ensuring availability of facilities and assistance for stability stock and the price is required.
\end{abstract}

\section{Introduction}

At the beginning of 2020, the world was shocked by the emergence of the Corona Virus Disease 2019 (C ovid -19) outbreak causing casualties and economic downturn, including Indonesia. Almost all regions either residents or communities, that having positive COVID19 [1]. Indonesian Government takes steps containment measures and prevention, including PSBB (large-scale social restrictions), limiting the operating hours of restaurants and supermarkets, using a mask, and prohibiting social distancing.

The declining economic growth including Indonesia, is one of the impact outbreaks of the Covid -19. The Indonesian government must take action to issues that require special policies related to (1) the a vailability of food stocks and supplies that will affect food prices

* Corresponding author: yennita.sihombing86@gmail.com 
stability; (2) travel restrictions and worker mobility that affect tourism and transportation; (3) disruption of production and supply chains that affect performance of the manufacturing sector and its derivatives; and (4) falling of world oil prices due to weakening demand and the oil price war between Saudi Arabia and Russia [2] .

Although the share of agricultural employment in total employment has decreased from 40.2 percent to 26.8 percent over the past two decades, agriculture provides the livelihoods of more than one billion people worldwide and remains the backbone of many low-income countries counting. 60.4 percent of total employment [3]. The agricultural sector is the main source of employment opportunities for women, covering 41.9 percent of the entire a gricultural workforce in developing countries [4]. Meanwhile, in the agricultural sector, women have a major role in the production, harvest and post-harvest processes which are able to make a large contribution in increasing their family income [5]. In Indonesia the a gricultural sector contribution to $9.23 \%$.

As the COVID-19 outbreak continues to spread across the globe, it is important to respond to existing and possible impacts on the agricultural sector, especially related to the food supply and demand perspective. This paper aims to look at the impact of the C ovid 19 outbreak on the agricultural sector and anticipate strategies that could be carried out for development of a gricultural sector during and after Covid-19.

\section{Research methods}

This article written according to the literature studies of various conditions and developments in the spread of the COVID-19 that is currently occurring in Indonesia. The Desk Research literature used was research and review papers from Ministry of Agriculture, BPS [6], as well as websites of national and international news, summarized into a scientific paper.

\section{Results and discussion}

The agricultural sector is one of the sectors that is affected by the Covid-19. The agricultural sector is a priority needs in dealing with the spread of Covid-19 because it is directly related to meeting the needs of human life which highly related to food demand. Despite the economic downturn in various business sectors, the agricultural sector is the last sector that can survive. As the agricultural sector is mostly cultivated by Indonesian citizen, it plays an important role in fulfilling the economy needs of most of them. BPS [6] shows that there is $87,50 \%$ in 2019 , people are work ing in the agricultural sector. In addition, the agricultural sector is the basis for the development of other economic sectors such as industry and services sections. The agricultural sector becomes a mainstay in fulfilling nation's food to overcome hunger [7].

Agriculture plays an important role in fulfilling the economy of most of the Indonesia citizen as data BPS shown the agricultural workforce sector at $87.50 \%$ in 2019 [6]. Therefore it is important that the developing of the agricultural sector including various government policies to fulfill the citizen's needs and support economic of people working in the agricultural sector, especially during the Covid-19 pandemic situation.

\subsection{The impact of the Covid-19 against on agriculture}

Indonesia's food demand with a large population requires the increasing of food supply. Meanwhile, the capacity to produce food tends to decline due to various factors, such as land limitation, reduced of the labor force, degradated soil fertility, and global climate 
change. These factors impact on the food supply [8]. Since the beginning of the pandemic, there have been no significant disruptions in the food supply (Figure 1). However, if the disruptions occur in the long term, it can affect logistic supply chain, especially crossborder and domestic movement, as well as the labor issues. There are commodities affected by the Covid-19 pandemic, such ashigh value and perishable food such as fresh fruits, vegetables, meat, fish, and milk [9].

According to the production and requirement forecasts from the BKP Kemtan, impact of the outbreak among others are: (1) decreased production by $5 \%$ due to the high price of production inputs (seed, fertilizer, pesticide and feed) and distribution problems. (2) Needs for food will increase by $5 \%$ due to panic buying and stocking food. (3) imports' realization will decrease by $5 \%$ due to export restrictions [10].

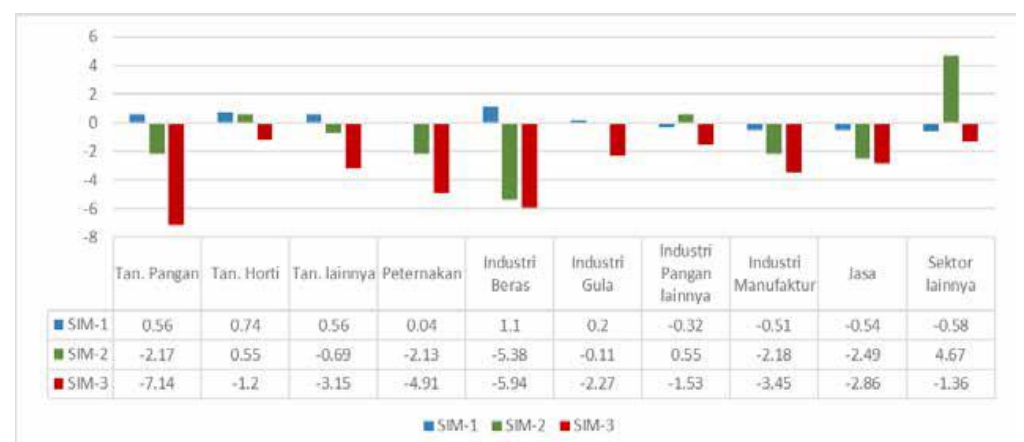

Source: Processed GTAP (2020)

Explanation: $\quad$ SIM-1 = Skenario Labor productivity shock; SIM-2 = Skenario Total factor productivity shock; and SIM-3 = Skenario Trade shock

Fig 3. The impact of the spread of COVID-19 on the export value of agricultural and nonagricultural commodities in Indonesia (\%)

\subsection{Changes in food supply chain patterns}

The system or work pattern in the food sector has changed significantly amid the COVID19 pandemic; from the production process to consumption, from upstream to downstream. From a production or upstream perspective, famers and food producers are starting to perceive changes in input supply and must adjust production protocols to ensure food quality and safety, particularly in contaminated areas.

The food supply chain is a complex network involving producers, agricultural inputs, transportation, processing industries, shipping to food products to consumers. At a time when the Covid-19 virus spreads and cases continue to increase, stricter measures are needed to contain its spread. So that, it has an impact on the food system. Various parties and experts continue to try to find out what should be done by studying the food system and supply chain. So that the food needs of the community are still met [11].

The food and foodstuffs' mobilization will undergo several adjustments due to changing supply lines towards modern markets and online-based markets. If we look at from the consumption side, transaction patterns have also begun to change. This is indicated by the increasing number of transactions using digital or online platforms due to the implementation of social/physical distancing or Large-scale Social Restrictions (PSBB) in several areas. This condition ultimately requires adjustment of food-related policy strategies on all lines (production to consumption and upstream to downstream). 
The strategy adopted is that the government must ensure that facilities and assistance in all lines of food, started from the production to the consumption. The aim is helping to improve the production performance. In the current pandemic situation, in addition to these facilities, a production protocol is also needed that can guarantee the quality and safety of food. It must free or un-affected by COVID-19. Coordination among institutions is the key to the success of implementing this food policy strategy.

\subsection{Food insecure}

The food crisis in Indonesia has long been felt by the community. Agricultural product and, livestock to local industries have experienced price increases every year. At the beginning of 2016, there was a food slump in Indonesia, with soaring food prices in the market [12]. This is shown by the data obtained from GHI /Global Hunger Index [13] in 2019 which reaches 20,1 point. In addition, in 2020, GHI Indonesia recorded that the point is 19,1 or decrease by 1 point than the previous year (the previous score in 2019 is 20,1). This shows that Indonesia can be categorized as in the serious category, which means that the level of hunger in Indonesia is really needs to be addressed. This global food crisis does not only occur in Indonesia but also in other developed countries, where this requires serious handling by all stakeholders at the all leveles (internationally, nationally and regionally).

The Covid-19 pandemic does not only affect the social-economic and cultural conditions, but also affects the food sovereignty. Food insecurity is the most real threat. This is because of there is a possibility that the Covid-19 pandemic could spread to villages because there is a movement of people from the Covid-19 red zone in cities, to villages. With the lack of infrastructure in the village, Covid-19 can threaten farmers who are the largest food producers [14].

The increasing of the unemployment rate in Agustus 2020 is 7,07 percent. It increased by 1,84 percent compared to Agustus 2019 that has occurred since the pandemic and has increased the number of workforce reductions has led to increased food insecurity, which created conditions for $23 \%$ of the population to have their usual level of consumption, and $36 \%$ of the population reduced their consumption level due to a decline in financial conditions [15].

\subsection{Agriculture in new normal era}

Agriculture in the new normal era shows that several obstacles have occurred. There are the increased input prices, disruption of supply chains, and reduced demand for certain agricultural products, especially tertiary products [16]. Recent data shows that the agricultural sector has contracted. In February 2020, the employment in the agricultural sector decreased by 60 thousand people or around 0.42 percent compared to last year. Economic growth in the first quarter of 2020 shows that the agricultural sector is only able to grow 0.02 percent on an annual basis. Even so, the agricultural sector still potentially become a foundation in stimulating economic growth. On a quarterly basis, agriculture product still growing 9.46 percent [17].

Although the government guarantees the availability of staple food, the problem faced is how the food can be distributed to the population in Indonesia. This relates to how the logistics system is most effective and safe by considering social distancing and physical distancing policies. To ensure that basic food supplies can be distributed to the entire population of Indonesia, the government is building a logistics system that is able to minimize crowds of buyers so as to minimize the potential for the spread of the Covid-19 outbreak. The conventional way of distribution that the government routinely does in 
dealing with rising food prices and food shortages includes market operations, non-cash food assistance for poor households, Toko Tani Indonesia Center [18].

Digitalization encourages the distribution of food products through $e$ commerce. Digitalization is conducted by embracing retail entrepreneurs, utilizing modern market and distribution systems along with distribution facilities (distribution center and store network) and operational system [19]. To minimize the spread of COVID-19 in the on-line food distribution systems, it is necessary to shorten the distance and travel time. Hadiutomo [20] proposes to decentra lize logistics.

\subsection{Government policy in handling the covid-19 pandemic}

The Indonesian government, both central and regional government, as well as related stakeholders, collaborate in formulating policies to address these economic impacts, such as: (a) maintaining the food availability and the food access for the people at affordable prices; (b) mapping the national food stocks, and early detection of areas that have risk of a food crisis; (c) improving the distribution channel for fertilizer subsidies for farming run effectively and efficiently and; (d) safeguarding the stability of food prices by increasing low-cost market activities (government subsidies) for households and MSMEs in the agricultural sector [21], and ensure that all facilities and assistance from production to consumers must run properly [22] .

The role of local governments is also important in dealing with the Covid-16 pandemic by reducing the use of budgets through these points: (1) Reallocation of the use of the honorarium budget, social assistance and grants to poor/underprivileged people; (2) Providing social assistance to the poor/underprivileged; (3) Application of the cash laborintensive pattern; (4) Adjustment of the implementation of activities that invite a large number of people. While the budget adjustment is intended for buying health and other matters related to the prevention and treatment of Covid-19; producing social safety nets; and handling of the economic impact, especially so that the business world remains alive [23].

The Ministry of Agriculture continues to manage and maintain food security in Indonesia. This is confirmed through the Minister of Agriculture Circular Number: $1 / \mathrm{SE} / \mathrm{KN} .010 / \mathrm{M} / 03 / 2020$ concerning the Strategy of the Ministry of Agriculture in the Context of Prevention and Protection from the Impact of COVID-19 Protection. The scenarios developed are: (1) optimistic scenario: when production, import realization and food demand are normal. (2) a moderate scenario, assuming that production falls by $5 \%$, demand increases by $5 \%$, and the realization of imports (garlic, beef/buffa lo, granulated sugar) falls by $5 \%$. (3) a pessimistic scenario, if production decreases by $10 \%$, demand increases by $10 \%$, and the realization of imports (garlic, beef/buffalo, granulated sugar) decrea se by $10 \%$ [24].

\subsection{Agricultural sector development strategy}

To prevent the decreasing performance of the agricultural sector, a reorientation of agricultural development policies and programs are needed [25]. The points regarding those policies and programs are: (1) Strengthening agricultural-based farmer empowerment and labor-intensive programs in villages with a cash for work model to reduce poverty in rural; (2) Ensuring the availability and access of food for the people at affordable prices; (3) Anticipating food price strike by carrying out accurate mapping of national food stocks, as well as early detection of areas at risk of food vulnerability; (4) Improve the distribution channel of fertilizer subsidies to farmers ; (5) simplifying the mechanism and requirements for KUR (public business credit) 
distribution; (6) Providing stimulus or incentives to farmers in maintaining and increasing agricultural production amidst the increasingly widespread pressure of the spread of COVID-19; (7) Food price stabilizing at farmer and consumer levels by including increasing low-cost market activities (government subsidies) for farmhouses and SMEs in the agricultural sector; (8) Stren gthening Indonesia's a gricultural exports amid the COVID-19 pandemic through increasing added value and competitiveness, optimize trade negotiations, and expand export markets to non-traditional tra ding countries .

The progress of agricultural and rural communities, as well as the rapid development of the economy, is motivated by the relatively strong organization of famer groups. An independent and strong economic organizational system for farmer groups can be easily developed if the structure of agricultural land tenure is relatively even. Group farming is an innovation whose adoption process is through a participatory process in build ing the ability of farmer groups to manage the work plans they have prepared to achieve common goals [26].

The Ministry of Agriculture issued a policy in 2020 agricultural development to rea lize advanced, independent and modern agriculture. To achieve this goal, there are 4 aspects that need to be the focus of attention. First, increasing production and productivity through a national movement to increase productivity and production of agricultural commodities and increase the capacity of agricultural human resources. Second, reducing agricultural costs to low-cost agriculture through increasing efficiency and developing corporate-based areas. Third, the development and application of mechanization and acceleration of the use of technological innovation. Fourth, agricultural expansion through expansion of land use including swamps and other sub-optimal areas as well as water supply (irrigation, reservoirs, and other water structures).

Another strategy in agricultural development is to integrate agricultural development with industry and services. This policy is reflected in the PP (Government regulations) No. 28 of 2008 that future industrial development should be integrated with the development of the agricultural sector. The existing environment support its possibility to build an a gricultural industry that in-line with the development of the service sector [27].

\section{Conclusion}

Agriculture is one of the main economic contributions. Agriculture in the new normal era shows that there are several obstacles that have occurred that had an impact on the global and local economies. The Indonesian government in central, provincial along with related stakeholders, has been collaborated in formulating policies to address these economic impacts. In anticipation of the impact of Covid-19 on the availability and stability of food prices, the government must ensure that all facilities and assistance from production to consumers must run properly.

\section{References}

1. Ministry of Health, Prevention and control guideline corona virus disease (Covid-19)rev4, https://www.kemkes.go.id/article/view/20031700001/Dokumen-Resmi-danProtokol-Penanganan-COVID-19.html(2020)

2. K. Hadiutomo, Agric. Dev. Plan. Bul. 1, 2, 18-27 (2020)

3. ILOSTAT, Employment by sex and economic activity - estimates using models from the ILO, November 2019, International Labor Organization: Department of Sectoral Policy (2019) 
4. ILO, world employment social outlook: Trends for women 2017, International Labour Organization: Sectoral Policy Department (2017)

5. B. Samadi, Profit of Harvesting and Organic System Pineapple Cultivation (Lily Publisher, Yogyakarta, 2014)

6. Central Bureau of Statistics, Employment statistics (Central Bureau of Statistics, Jakarta, 2019).

7. Khairad, F., J. Agriuma 2, 2, 82-89 (2020)

8. A.A. Sulaiman, The success of Indonesia's self-sufficiency in becoming the world's food barn 2045. (IAARD Press, Jakarta, 2018)

9. B.R.D. Wulandani, A. Wiwin, J. Pengab. Masy. Berkemaja un 4, 1, 386-390 (2020)

10. K. Hadiutomo, The impact of the corona virus outbreak: when we are forced to be"more" digital, Articles of E-Commerce Logistics, 18 Maret 2020 (2020)

11. L. Poppick, The effects of Covid-19 will ripple through food systems: staplecrops are likely to be less affected by measuresto control the virus, but farmers growing more specialized ones could feel the pinch, Public Health, American Scientific dalam https://www.scientificamerican.com/article/the-effects-ofcovid-19-willrippleroughfood-systems/ (2020)

12. Atem, N. Niko, J. Surya Masy. 2, 2, 94-104 (2020)

13. Anonimous, Global hunger index: the challenge of hunger and climate change. https://www.globalhungerindex.org/pdf/en/2019.pdf. (2019)

14. Abdullah, S., The threat of food insecurity in the midst of the Covid-19 pandemic, https://kedaulatangangan.org/ancaman-rawan-pangan-di-tengah-pandemi-covid-19/ (2020)

15. H.N. Ulya, J. Islamic Econ. Bus. 3, 1, 80-109 (2020)

16. Z. Rozaki, Covid-19, Agriculture and food security in Indonesia, Presented on Internasional Webinar "Southeast Asian Agriculture Post Covid-19 Pandemi: Current and Future Perspectives" on 11 Juli 2020 (2020)

17. Central Bureau of Statistics, Indonesia's employment situation February 2020, No.40/05/Th. XXIII, 05 Mei 2020, Central Bureau of Statistics, Jakarta (2020)

18. D.S. Simbolon, Agric. Dev. Plan. Bul. 1, 2, 63-74 (2020)

19. Setijadi, Building a COVID-19 Pandemic Emergency Response Logistics System, https://jurna lmaritim.com/menbangun-sistemlogist ik-trespon-darurat-pandemi-covid$19(2020)$

20. K. Hadiutomo, Agric. Dev. Plan. Bul. 1, 2, 18-27 (2020)

21. Ministry of Agriculture, The impact of Covid-19 on the agricultural sector (Planning Bureau of the Secretariat General of the Ministry of Agriculture, Agricultural development planning bulletin, 2020)

22. F.B. Hirawan, A.A. Verselita, Food policy during the Covid-19 pandemic (CSIS Indonesia, Jakarta, 2020)

23. M.Z.B. Tjenreng, Government and local government policies in handling Covid-19 and its impact on the national economy, presented in a webinar: ARS University, Yogyakarta (2020)

24. S.A. Rohmani, Agric. Dev. Plan. Bul. 1, 2, 42-55 (2020)

25. Hermanto, Agric. Dev. Plan. Bul. 1, 2, 6-17 (2020)

26. C. Gustiana, Agrisamudra 2, 1, 71-80 (2015)

27. T.N. Aziza, Looking at agricultural development policies, National Institute of Public Administration Republic of Indonesia (2020) 